\title{
Autosomal spastic paraplegia type 72
}

INSERM

\section{Source}

INSERM. (1999). Orphanet: an online rare disease and orphan drug data base. Autosomal spastic paraplegia type 72. ORPHA:401849

Autosomal spastic paraplegia type 72 is a rare, genetic, pure hereditary spastic paraplegia disorder characterized by early childhood onset of slowly prog ressive crural spastic paraparesis presenting with spastic gait, mild stiffness at rest, hyperreflexia (in lower limbs), extensor plantar responses and, in some, mild postural tremor, pes cavus, sphincter disturbances and sensory loss at ankles. 